\title{
Physiology of the Conjugation Process in the Yeast Hansenula wingei
}

\author{
By T. D. BROCK* \\ Department of Biology, Western Reserve University, Cleveland 6, Ohio, U.S.A.
}

(Received 20 April 1961)

\begin{abstract}
SUMMARY
The yeast Hansenula winge $i$ is a favourable organism for study of the physiology of the conjugation process (cell fusion). Microscopic observations on fusion are presented which reveal that the mating cells in contact fuse by a softening of the cell wall, followed by formation of a conjugation tube, dissolution of the cross-walls between them, and formation of a new bud at the point of juncture of the two cells. A simple technique for studying fusion in a liquid medium is described. Up to $80 \%$ of the cells will fuse in $5 \mathrm{hr}$. at $30^{\circ}$ in a medium containing an energy source, $\mathrm{MgSO}_{4}$ and potassium phosphate, under conditions in which no growth or budding of unmated cells would occur. Synthesis of new protein is required for fusion as shown by inhibition by amino acid analogues. The precursors for this new protein come from the amino acid pool. Both mating types must be able to function for conjugation to occur. It is postulated that each mating type produces an inducer which diffuses into the opposite type. Each inducer brings about the synthesis of a wall-softening enzyme which acts upon the cell producing it. Cell fusion is viewed as an extension of the normal budding process.
\end{abstract}

\section{INTRODUCTION}

The physiology of reproduction in fungi was reviewed by Hawker in 1957. It is clear from this review how meagre is knowledge of the biochemical processes involved in reproduction. In particular, there has been no analysis of the physiological processes involved in cell fusion, the first step in the mating cycle in fungi and most other organisms. As Hawker emphasized, the higher fungi are not suitable for such an analysis, partly because they are difficult to handle and partly because differentiation of cells into various types, some involved in mating and some not, makes an analysis at the cellular level difficult.

The yeasts would seem to be more favourable material for such studies. In a sexually reproducing yeast each cell may function either in vegetative growth or in mating. In the heterothallic yeasts, two mating types occur, genetically determined, which can be kept in culture indefinitely as haploid strains. Mating can then be induced at will by mixing the two mating types.

The only earlier work on mating in yeast is that of Nickerson \& Thimann (1941, 1943). The present work is an outgrowth of studies on the nature of the mating reactions in Hansenula wingei. This yeast, isolated by Wickerham (1956), is unusual

* Present address: Department of Bacteriology, Indiana University, Bloomington, Indiana, U.S.A. 
in that cells of the two mating types exhibit an extremely strong attraction for each other, so that when mixed in mass culture, a marked agglutination occurs. Analysis of the nature of the attractive forces (Brock, $1959 a, b$ ) showed that one mating type, strain 5 , possesses a specific carbohydrate on its cell wall, whereas the other mating type, strain 21, possesses a specific protein. Mating agglutination is due to a combination between these complementary macromolecules, analogous to a reaction between an antibody and antigen. Because of the strong attraction between the mating types, cells can be mixed and remain in contact throughout extensive aeration and other physiological manipulation, and during this time cell fusion occurs. It has thus been possible to examine some of the factors involved in the fusion process. Preliminary accounts of this work have been given (Brock, 1959c, $d$ ).

\section{METHODS}

Strains used. The yeasts used in this study were supplied by Dr L. J. Wickerham, U.S. Department of Agriculture, Peoria, Illinois, U.S.A. They were Hansenula wingei NRRL Y-2340, strains 5 and 21, which were the agglutinative mating types.

Growth of cells. The cells were grown in liquid medium of the following composition: glucose 30 g., yeast extract Difco (Detroit, Michigan, U.S.A.) 7 g., $\mathrm{KH}_{2} \mathrm{PO}_{4} 5$ g., in $1000 \mathrm{ml}$. distilled water. This medium was dispensed in $100 \mathrm{ml}$. amounts into $500 \mathrm{ml}$. Erlenmeyer flasks, autoclaved $15 \mathrm{~min}$., $121^{\circ}$, and inoculated with cells from stock agar slopes. The flasks were then placed on a reciprocating shaker and incubated for $18 \mathrm{hr}$. at $30^{\circ}$. The cells were harvested by centrifugation, washed twice with distilled water and suspended in distilled water at the same cell concentration as in the growth medium.

Cell fusion assay. Mating was carried out by mixing together $5 \mathrm{ml}$. amounts of suspensions of each cell type with $0.1 \%(\mathrm{w} / \mathrm{v}) \mathrm{MgSO}_{4} .7 \mathrm{H}_{2} \mathrm{O}$ and centrifuging for 5 min. The packed cells became intimately mixed and agglutinated strongly. The supernatant fluid was then decanted and the packed cells resuspended in $10 \mathrm{ml}$. of conjugation medium (glucose, $1 \%$, w/v; potassium phosphate ( $\mathrm{pH} 5 \cdot 7$ ); $\mathrm{MgSO}_{4} \cdot 7 \mathrm{H}_{2} \mathrm{O}$, $0.1 \%, \mathrm{w} / \mathrm{v})$. Although the cells resuspended poorly because of the agglutination, the mixture was made as homogeneous as possible. This suspension was then poured into a 1 in. diameter shell glass vial which was then placed on a reciprocating shaker at $150 \mathrm{rev} . / \mathrm{min}$. Usually the vials were shaken for $5 \mathrm{hr}$. at $30^{\circ}$. At this time the suspension, which was still quite agglutinable, was decanted into a centrifuge tube and sedimented. The supernatant fluid was discarded and the cells suspended in $10 \mathrm{ml} .8 \mathrm{M}$-urea. The suspension was placed in an autoclave for 10-15 min. at $120^{\circ}$ to deagglutinate the cells, the $8 \mathrm{M}$-urea serving to keep the cells from reagglutinating when they cooled down. Although this treatment effectively converted the clumped cells to a fine suspension, the conjugated cells remained together when fusion had occurred. It was then possible to take small samples of these cells, stain them with dilute crystal violet, and examine them under oil immersion at $\times 950$ magnification. The number of conjugants and the total number of cells were counted in a number of microscope fields. From these data the $\%$ conjugation was calculated by the method of Nickerson \& Thimann (1943), counting each conjugating pair as two cells and each single cell as one cell. The data presented here report the 
$\%$ of conjugants. This procedure assumes that there is no lysis or destruction of cells during the autoclaving and $8 \mathrm{M}$-urea treatment. There was no evidence that such destruction did occur.

\section{RESULTS}

\section{Microscopical observations of conjugation}

Cells of each strain grown for $24 \mathrm{hr}$. in glucose yeast-extract $\mathrm{KH}_{2} \mathrm{PO}_{4}$ broth on the shaker were mixed in equal parts in the same medium containing $20 \%(\mathrm{w} / \mathrm{v})$ gelatin, the mixture placed on a coverslip on a hanging-drop slide, ringed with paraffin wax and observed under a Leitz phase microscope at room temperature. At the cell concentrations used about one-half of the cells were single, and the other half occurred
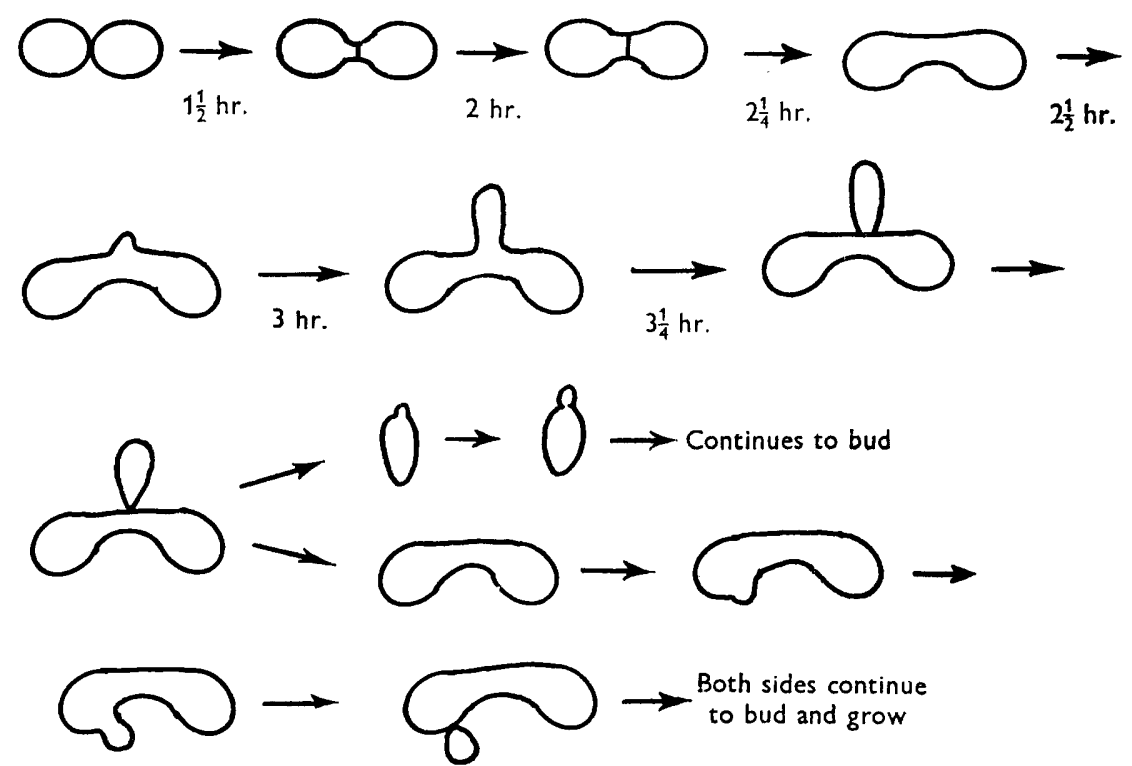

Fig. 1. Details of conjugation process in Hansenula wingei. Diagrammatic representation of observations with phase microscope of conjugating cells in glucose + yeast extract + phosphate broth $+20 \%(\mathrm{w} / \mathrm{v})$ gelatin at room temperature.

in pairs touching each other. The single cells budded but never exhibited any attraction for adjacent cells. Pairs of cells in contact were observed over a period of 4-5 hr. for conjugation behaviour. The results of the observations are shown in the diagram (Fig. 1). In the first 1-1 $\frac{1}{2}$ hr. the cells in contact showed no visible behaviour. By $2 \mathrm{hr}$. many of the paired cells showed conjugation tubes. These tubes were observed to form by an extension of the portion of each cell at the point where it touched its mate. It should be emphasized that at no time were conjugation tubes observed to be formed by growth together of two separated cells, but always by an extension of each of the two cells in contact. In effect, the formation of the conjugation tube was due to each cell pushing its main body away from its mate. The conjugation tube appeared to result from a softening of the cell wall. In Saccharomyces cerevisiae Levi (1956) observed conjugation processes between cells not in contact, implying that some extracellular substance induced the process. There was no evidence for such a situation with the organism used in the present work. 
At first the cross-walls between the two cells remained intact. At about $2 \mathrm{hr}$. the cross-walls disappeared. This occurred during a short period of time and was often missed. In one case the cross-walls disappeared within a 10 min. period.

Shortly after the cross-walls disappeared, a small bud formed at the mid-point of the conjugation tube and at a right angle to it. It is assumed that the bud formed here because this was the softest part of the wall. This small bud grew rapidly and by $3 \mathrm{hr}$. appeared to be fully grown. Shortly after $3 \mathrm{hr}$. a wall between this bud and the parent cells was quickly formed, often being complete in 5-10 min. This new bud always seemed longer than either of the parent cells, often appearing moderately filamentous. After enlarging fully this first bud could then form new buds, usually from the tip. Later, this bud on the conjugation tube might become completely detached from the parents.

Later, the parent cells often budded individually from locations far removed from the conjugation tube. These buds were morphologically similar to the parents, rather than elongated like the conjugation tube bud. Nothing is known about the nuclear phenomena in the mating process, and no bodies which could definitely be called nuclei were seen. It is assumed that after the cross-wall in the conjugation tube dissolves, nuclei from each parent can move into the tube and either fuse or remain separate. In either case there must be nuclear migration into the bud which forms off the conjugation tube, and this new bud must acquire nuclear material from both parents. Preliminary genetic evidence (Herman, 1959) suggests that the hybrids from matings possess characteristics of both strains but may be heterocaryons instead of true diploids.

In the physiological studies which follow, the only process under consideration is cell fusion and the formation of conjugation tubes. Later stages of growth of the mated cells are not considered and probably do not occur, since the medium used in most studies is inadequate for growth.

\section{Physiology of conjugation}

A preliminary experiment was made to determine the time course of conjugation under the conditions selected. In this experiment the conjugation medium was the growth medium. As shown in Table 1, conjugation began after about $1 \frac{1}{2} \mathrm{hr}$. and reached about $50 \%$ after $4-5 \mathrm{hr}$. In later experiments with other conjugation media the $\%$ conjugation was somewhat higher. A time of $5 \mathrm{hr}$. was selected for all subsequent experiments.

Table 1. Time course of conjugation in Hansenula wingei

Cells of strains 5 and 21 were mixed and suspended in conjugation medium (glucose + yeast extract + phosphate) and shaken for various times at $30^{\circ}$; samples removed and assayed microscopically for \% conjugants as described in Methods.

$\begin{array}{lccc}\begin{array}{c}\text { Time } \\ (\mathrm{hr} .)\end{array} & \begin{array}{c}\text { Conjugants } \\ (\%)\end{array} & \begin{array}{c}\text { Time } \\ (\mathrm{hr} .)\end{array} & \begin{array}{c}\text { Conjugants } \\ (\%)\end{array} \\ 0 & 0 & 2 \cdot 5 & 40 \\ 0.5 & 0 & 3.0 & 47 \\ 1 \cdot 0 & 0 & 4 \cdot 0 & 47 \\ 1 \cdot 5 & 8.5 & 6.0 & 57 \\ 2 \cdot 0 & 32 & & \end{array}$


The effect of various nutrient factors on conjugation was studied next, and the results are in Table 2. In all cases except with water the cells remained firmly clumped throughout the incubation period on the shaker; the cells in water, however, no longer remained agglutinated. This is in line with previous observations that cations are necessary for agglutination. Therefore, in all subsequent experiments $0 \cdot 1 \%(\mathrm{w} / \mathrm{v}) \mathrm{MgSO}_{4} \cdot 7 \mathrm{H}_{2} \mathrm{O}$ was present in the conjugation medium. Further data in Table 2 indicate that no conjugation occurred unless glucose was present; neither yeast-extract nor casein hydrolysate replaced glucose. An added nitrogen source was not necessary for conjugation.

\section{Table 2. Nutrient requirements for conjugation in Hansenula wingei}

Cells of strains 5 and 21 were mixed and suspended in the media indicated, shaken $5 \mathrm{hr}$. at $30^{\circ}$, then assayed microscopically for $\%$ conjugation as described in Methods.

Composition of conjugation medium

Conjugants at $5 \mathrm{hr}$.

\section{Water}

$0 \cdot 1 \%(\mathrm{w} / \mathrm{v}) \mathrm{MgSO}_{4} \cdot 7 \mathrm{H}_{2} \mathrm{O}$

0.05 M-phosphate (pH 5.7) $+0 \cdot 1 \%(w / v) \mathrm{MgSO}_{4} .7 \mathrm{H}_{2} \mathrm{O}$

$1.0 \%(\mathrm{w} / \mathrm{v})$ glucose $+0.05 \mathrm{M}$ phosphate $+0.1 \%(\mathrm{w} / \mathrm{v}) \mathrm{MgSO}_{4} \cdot 7 \mathrm{H}_{8} \mathrm{O}$

$1.0 \%$ yeast extract $+0.05 \mathrm{M}$ phosphate $+0.1 \%(\mathrm{w} / \mathrm{v}) \mathrm{MgSO}_{4} .7 \mathrm{H}_{2} \mathrm{O}$

$<1$

$<1$

2

$1.0 \%$ casein hydrolysate $+0.05 \mathrm{M}$ phosphate $+0.1 \%(\mathrm{w} / \mathrm{v}) \mathrm{MgSO}_{4} \cdot \mathbf{7 H}_{2} \mathrm{O}$

$0.5 \% \mathrm{NH}_{4} \mathrm{NO}_{3}+0.05 \mathrm{M}$ phosphate $+0.1 \%(\mathrm{w} / \mathrm{v}) \mathrm{MgSO}_{4} .7 \mathrm{H}_{2} \mathrm{O}$

$1.0 \%$ glucose $+0.5 \%(\mathrm{w} / \mathrm{v}) \mathrm{NH}_{4} \mathrm{NO}_{3}+0.05 \mathrm{~m}$ phosphate $+0.1 \%(\mathrm{w} / \mathrm{v})$

$\mathrm{MgSO}_{4} \cdot 7 \mathrm{H}_{2} \mathrm{O}$

$1.0 \%$ glucose $+1.0 \%$ casein hydrolysate $+0.05 \mathrm{~m}$ phosphate $+0.1 \%(\mathrm{w} / \mathrm{v})$

$\mathrm{MgSO}_{4} \cdot 7 \mathrm{H}_{2} \mathrm{O}$

$3 \%(w / v)$ glucose $+0.7 \%(w / v)$ yeast extract $+0.5 \%(w / v) \mathbf{K H}_{2} \mathbf{P O}_{4}$

(growth medium)

\section{Table 3. Effect of energy source on conjugation in Hansenula wingei}

Cells of strains 5 and 21 were mixed and suspended in conjugation media containing $0.05 \mathrm{M}$ phosphate buffer $(\mathrm{pH} 5 \cdot 7)+0.1 \%(\mathrm{w} / \mathrm{v}) \mathrm{MgSO}_{4} .7 \mathrm{H}_{2} \mathrm{O}+$ energy source as indicated, then shaken $5 \mathrm{hr}$. at $30^{\circ}$ and assayed microscopically for \% conjugants as described in Methods.

\section{Energy source $(\%, w / v)$}

Glucose, 1.0

Glycerol, 2.0

Ethanol, 4.0

Mannose, 1.0

Galactose, 1.0

\section{Conjugation at $5 \mathrm{hr}$.} (\%)

69

51

17

50

4
Energy source $(\%, w / v)$

Sucrose, 0.5

Lactose, $\mathbf{0 . 5}$

Trehalose, 0.5

$\mathrm{Na}$ citrate, 1
Conjugation at $5 \mathrm{hr}$.

(\%)

40

2

15

A study of energy sources for conjugation was carried out with the results shown in Table 3. Only substances which had been reported by Wickerham (1956) to be utilized for growth by this organism were useful as energy sources for conjugation. In all subsequent experiments the conjugation medium used was: $1.0 \%(\mathrm{w} / \mathrm{v})$ glucose, $0 \cdot 1 \%(\mathrm{w} / \mathrm{v}) \mathrm{MgSO}_{4} .7 \mathrm{H}_{2} \mathrm{O}, 0 \cdot 05 \mathrm{M}$-potassium phosphate buffer (pH 5.7).

No growth occurred in this simple medium as shown by the following experiment. Cells of each strain were suspended separately in the conjugation medium and incubated for $5 \mathrm{hr}$., then samples removed and examined under the microscope. The number of single cells, budding cells, unequal pairs and equal pairs were counted (Campbell, 1957) to indicate whether growth had occurred; the total count was also 
determined. The results after $5 \mathrm{hr}$. were compared with results obtained with unincubated cells. Table 4 shows that there was neither an increase in total numbers of cells nor an increase in number of budding cells. The number of buds and pairs decreased, while the number of single cells increased. The increase in number of single cells indicates that cell separation was the main process which occurred in this non-growth medium.

Table 4. Budding and growth of cells of Hansenula wingei during 5 hr. incubation in conjugation medium

Cells not mated, but suspended separately in conjugation medium (glucose $+\mathrm{MgSO}_{4}+$ phosphate), shaken for $5 \mathrm{hr}$. at $30^{\circ}$, then examined microscopically and buds enumerated.

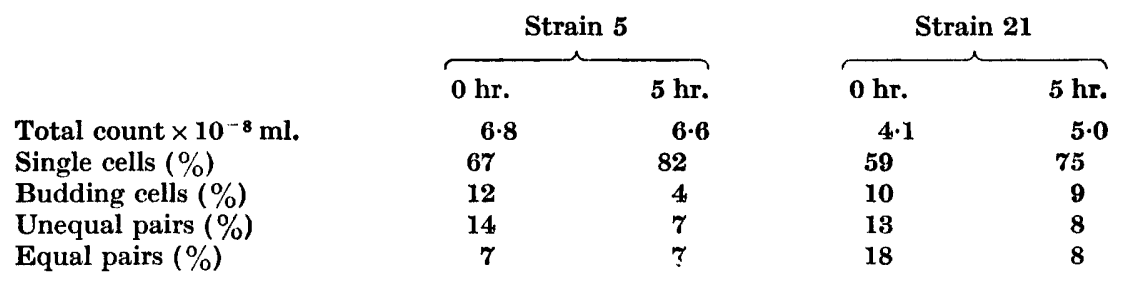

Both cell types must function in the conjugation process; this was shown in several ways. The antibiotic cycloheximide (Actidione; The Upjohn Co., Kalamazoo, Michigan, U.S.A.) completely inhibited conjugation at concentrations which inhibited growth. The wild-type cells were completely inhibited by cycloheximide $0.5 \mu \mathrm{g} . / \mathrm{ml}$. Antibiotic-resistant mutants were isolated from both mating types by periodic transfer to agar containing increasing concentrations of cycloheximide until mutants resistant to $100 \mu \mathrm{g}$. $/ \mathrm{ml}$. were obtained. (These strains were isolated by Miss Alberta Herman and Mr D. Hunt.) The resistant mutants agglutinated and conjugated normally, both with each other and with wild-type cells. Table 5 shows the results when these mutants were mated with wild types in all combinations, with and without cycloheximide. Conjugation occurred in the presence of cycloheximide only when both strains were resistant, indicating that both strains must function for conjugation to occur.

Table 5. Conjugation of cycloheximide-resistant mutants and wild-type cells of Hansenula wingei with and without antibiotic

Cells of the two strains were mixed and suspended in conjugation medium (glucose + $\mathrm{MgSO}_{4}+$ phosphate), shaken for $5 \mathrm{hr}$. at $30^{\circ}$, then \% conjugants determined microscopically as described in Methods.

\begin{tabular}{|c|c|c|c|}
\hline 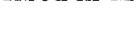 & & \multicolumn{2}{|c|}{$\%$ Conjugation } \\
\hline Strain 5 & Strain 21 & $\begin{array}{c}\text { No } \\
\text { antibiotic }\end{array}$ & $\begin{array}{c}\text { Cycloheximide } \\
1 \mu \mathrm{g} . / \mathrm{ml} .\end{array}$ \\
\hline Wild & Wild & 72 & $\mathbf{0}$ \\
\hline Wild & Fesistant & 57 & $\mathbf{0}$ \\
\hline Resistant & Wild & 59 & 0 \\
\hline Resistant & Resistant & 63 & 71 \\
\hline
\end{tabular}

This same conclusion can be drawn from the action of ultraviolet (u.v.) radiation on the conjugation process. Washed cells of both strains were irradiated under a General Electric germicidal lamp at a distance of $15 \mathrm{~cm}$. The cell suspensions were 
$5 \mathrm{ml}$. amounts in flat-bottom Petri dishes and were agitated continually during irradiation. These irradiated samples were then mated with unirradiated cells of the opposite type and conjugation allowed to occur. All operations were carried out in subdued light or in darkess to avoid photo-reactivation. As can be seen from Table 6, conjugation was quickly affected by short exposures to u.v. radiation. Viable counts of these irradiated cells indicated that ability to form colonies decreased at roughly the same rate as did ability to conjugate. These results also indicate that both types must function in the conjugation process.

Table 6. Conjugation of ultraviolet-irradiated cells with unirradiated cells of opposite type of Hansenula wingei

Cells of each strain were irradiated separately, then mixed with unirradiated cells of opposite mating type, shaken for $5 \mathrm{hr}$. at $30^{\circ}$ in conjugation medium (glucose $+\mathrm{MgSO}_{4}+$ phosphate), then assayed microscopically for \% conjugants as described in Methods.

$\begin{array}{ccc}\begin{array}{c}\text { Time of } \\ \text { exposure to u.v. } \\ \begin{array}{c}\text { radiation } \\ \text { (sec.) }\end{array}\end{array} & \begin{array}{c}\text { Strain } 5 \\ \text { irradiated }\end{array} & \begin{array}{c}\text { Strain 21 } \\ \text { irradiated }\end{array} \\ 0 & 68 & 68 \\ 5 & 56 & 52 \\ 10 & 38 & 45 \\ 20 & 21 & 33 \\ 30 & 20 & 19 \\ 60 & 2 & 2\end{array}$

The action of a number of metabolic inhibitors is presented in Table 7, showing that the usual metabolic inhibitors prevented conjugation.

\section{Table 7. Inhibition of conjugation in Hansenula wingei by metabolic inhibitors}

Cells of two mating types were mixed and suspended in conjugation medium (glucose + $\mathrm{MgSO}_{4}+$ phosphate) containing various additions as indicated, shaken $5 \mathrm{hr}$. at $30^{\circ}$, then assayed microscopically for $\%$ conjugants as described in Methods.

\begin{tabular}{|c|c|c|c|}
\hline Treatment & $\begin{array}{c}\% \\
\text { Conjugation } \\
\text { at } 5 \mathrm{hr} .\end{array}$ & Treatment & $\begin{array}{c}\% \\
\text { Conjugation } \\
\text { at } \mathbf{5} \mathrm{hr} .\end{array}$ \\
\hline Control & 76 & Dinitrophenol, 0.001 M & 4 \\
\hline $\mathrm{KCN}, 0.05 \mathrm{M}$ & 4 & $\mathrm{Na}$ azide, $0.001 \mathrm{M}$ & $\mathbf{0}$ \\
\hline Na arsenate, $0.001 \mathrm{M}$ & 63 & Boric acid, 0.025 M & $\mathbf{0}$ \\
\hline $\mathrm{Na}$ arsenite, $0.001 \mathrm{M}$ & $\mathbf{0}$ & Nystatin, $10 \mu \mathrm{g} . / \mathrm{ml}$. & $\mathbf{0}$ \\
\hline
\end{tabular}

Because of the marked morphological changes which occur during conjugation, it seems reasonable to assume that in each cell type there is the synthesis of an enzyme(s) which softens and eventually dissolves the wall between the cells. If enzymes are synthesized for this process, they might be inducible and might be synthesized de novo from constituents of the cell. It was shown by Spiegelman \& Halvorson (1953) that induced enzyme synthesis in Saccharomyces makes use of the free amino acid pool of the cells for the materials needed for protein synthesis. Several experiments were therefore made to see whether the free amino acid pool is necessary for conjugation in Hansenula wingei. Although no quantitative determinations were made, this organism was found to possess an extensive amino acid pool which was extractable by hot water and which reacted with ninhydrin. This pool 
was diminished effectively by starvation of the cells by aeration in $1 \%(\mathrm{w} / \mathrm{v})$ glucose +0.05 M-phosphate buffer ( $\mathrm{pH} \mathrm{5.7)}$ ). After aeration for $4 \mathrm{hr}$. there was no more ninhydrin-reacting material extractable by hot water remaining in the cells. Table 8 shows qualitatively the amino acid pool of these starved cells and the ability of starved cells to conjugate. These results show that starvation to decrease the free amino acid pool also decreased the number of conjugants, although the pool seemed to diminish faster than did the ability to conjugate. Spiegelman \& Halvorson (1953) showed that a considerable degree of induced enzyme synthesis occurred even after there was no detectable amino acid pool.

Table 8. Conjugation and amino acid pools of starved cells of Hansenula wingei

Cells starved in glucose + phosphate for various times as indicated. Samples removed for extraction of amino acid pools with hot water, and amount of pool determined quantitatively by reaction with $0.2 \%(\mathrm{w} / \mathrm{v})$ ninhydrin in acetone at $100^{\circ}$ for $10 \mathrm{~min}$. Remaining cells of each type mixed, suspended in conjugation medium (glucose $+\mathrm{MgSO}_{4}+$ phosphate), shaken for $5 \mathrm{hr}$. at $30^{\circ}$, then assayed microscopically for $\%$ conjugants as described in Methods.

\begin{tabular}{|c|c|c|c|}
\hline \multirow[b]{2}{*}{ Treatment } & \multirow{2}{*}{$\begin{array}{c}\% \\
\text { Conjugation }\end{array}$} & \multicolumn{2}{|c|}{ Ninhydrin reaction } \\
\hline & & Strain 5 & Strain 21 \\
\hline None & 64 & ++ & +++ \\
\hline $1 \mathrm{hr}$. starvation & 68 & + & + \\
\hline $2 \mathrm{hr}$. starvation & 61 & + & + \\
\hline 4 hr. starvation & $\mathbf{5 0}$ & \pm & - \\
\hline 7 hr. starvation & 8 & 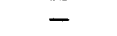 & - \\
\hline
\end{tabular}

Another experiment which confirmed the above results made use of the amino acid analogues $p$-fluorophenyl-alanine and ethionine which are specific antagonists of phenylalanine and methionine, respectively. Table 9 shows the effect of these substances.

Table 9. Effect of amino acid antagonists on conjugation in Hansenula wingei

Cells of two mating types mixed and suspended in conjugation medium (glucose + $\mathrm{MgSO}_{4}+$ phosphate) containing various additions as indicated, shaken $5 \mathrm{hr}$. at $30^{\circ}$, then assayed microscopically for \% conjugants as described in Methods.

\section{Treatment}

\section{None}

Fluorophenylalanine, $0.02 \mathrm{M}$

Fluorophenylalanine, $0.02 \mathrm{M}+$ phenylalanine, $0.02 \mathrm{M}$

Phenylalanine, $0.02 \mathrm{M}$

Ethionine, 0.02 M

Ethionine, 0.02M + methionine, $0 \cdot 02 \mathrm{M}$

Methionine, $0.02 \mathrm{M}$

\%
Conjugation
66
0
75
68
24
67
69

From a consideration of these results, the following hypothesis seems tenable. When the two mating types are brought together, there is a reciprocal induction in each type by its opposite mating type of an enzyme which softens and eventually digests its own cell wall. Thus the two cells form a conjugation tube between them, and eventually their cytoplasms mix and fusion is completed. The enzyme which is induced may be similar to, or identical with, the normal budding enzyme responsible 
for the small hole in the yeast wall through which the bud develops (Nickerson \& Falcone, 1956). The only difference is that in the present case the enzyme does not act randomly on the wall, but always at the point where the two cells touch. Support for this hypothesis is shown in the following experiment, where one cell type stimulated budding in the opposite type under conditions in which fusion could not take place. U.v.-irradiated cells of one type were mixed with non-irradiated cells of the opposite type and incubated for $5 \mathrm{hr}$. This experiment was performed with cells irradiated for $60 \mathrm{sec}$, since this irradiation time completely inhibited conjugation. After incubation the cells were de-agglutinated as usual, and the number of budding cells counted and compared with the number of budding cells in controls incubated unmixed. In the results given in Table 10, the $\%$ of buds was calculated from only those cells which showed young buds indicative of new bud formation. It is impossible to know which buds are on strain 5 cells and which are on strain 21 cells, but since little bud formation occurs when normal or irradiated cells are incubated separately, or when irradiated cells of both types are incubated together, it seems clear that when irradiated cells of one type are incubated with unirradiated cells of the opposite type, the unirradiated cells are stimulated to bud. This might be due to induction of the conjugation (or budding) enzyme by contact with cells of the opposite mating type.

Table 10. Number of buds on mated ultraviolet-treated cells of Hansenula wingei

Cells were irradiated 1 min. (sufficient to diminish conjugation to less than $1 \%$ ), then mixed with irradiated or non-irradiated cells of opposite type as indicated, then suspended in conjugation medium (glucose $+\mathrm{MgSO}_{4}+$ phosphate) and shaken $\mathbf{5} \mathrm{hr}$. at $30^{\circ}$. Cells then processed in the same way as in standard conjugation assay, and the $\%$ of budding cells determined microscopically. No detectable conjugation was seen.

$\begin{array}{lc} & \text { Buds } \\ & (\%) \\ \text { Strain 5, u.v. + Strain 21, u.v. } & 8 \\ \text { Strain 5, u.v. + Strain 21, normal } & 29 \\ \text { Strain 5, normal + Strain 21, u.v. } & 24\end{array}$

\section{DISCUSSION}

These studies have revealed a number of new points about the process of conjugation. In the following discussion, conjugation is defined as the process of cell fusion and implies nothing about nuclear interactions or other related events.

In Hansenula wingei conjugation occurs only when the two cells of the mating pair are in contact with each other. Conjugation will occur in the absence of growth, in a medium containing only an energy source, magnesium sulphate and potassium phosphate. The addition of nitrogenous compounds is of no benefit to the fusion process. Inhibitors which prevent energy metabolism prevent the fusion process.

Both cell types must function in the fusion process, and fusion will be inhibited when either of the two cells of the mating pair is treated with u.v. radiation or with cycloheximide. The process therefore differs from mating in Escherichia coli (Wollman, Jacob \& Hayes, 1956) which appears to require only one of the mating pairs, the DNA donor, to be active.

Synthesis of new protein is required for fusion to occur, and this synthesis of protein can be inhibited by amino acid analogues. The precursors for the synthesis of 
this new protein probably come from the free amino acid pool. It seems reasonable to assume that the new protein synthesized is a wall-softening enzyme, the synthesis of which is induced in each cell by contact with its mate. Evidence for this enzyme has been advanced by showing that when a cell is in contact with an u.v.-treated cell of the opposite type, the untreated cell is induced to bud, whereas new buds do not normally occur in the conjugation medium. The hypothesis is that the wall-softening enzyme presumed to be involved in cell fusion is similar to, or identical with, that involved in normal budding, and that during conjugation it is synthesized in large amounts, its action being localized at the point of contact of the mating cells. Thus conjugation can be viewed as an extension of the normal budding process. The fact that the first bud of the conjugant always occurs at the point of the conjugation tube midway between the two cells, where the wall is presumably the softest, is in keeping with this hypothesis (see Fig. 2).

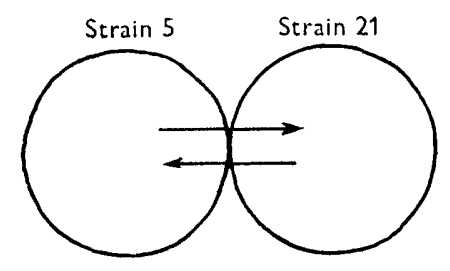

Inducers diffuse
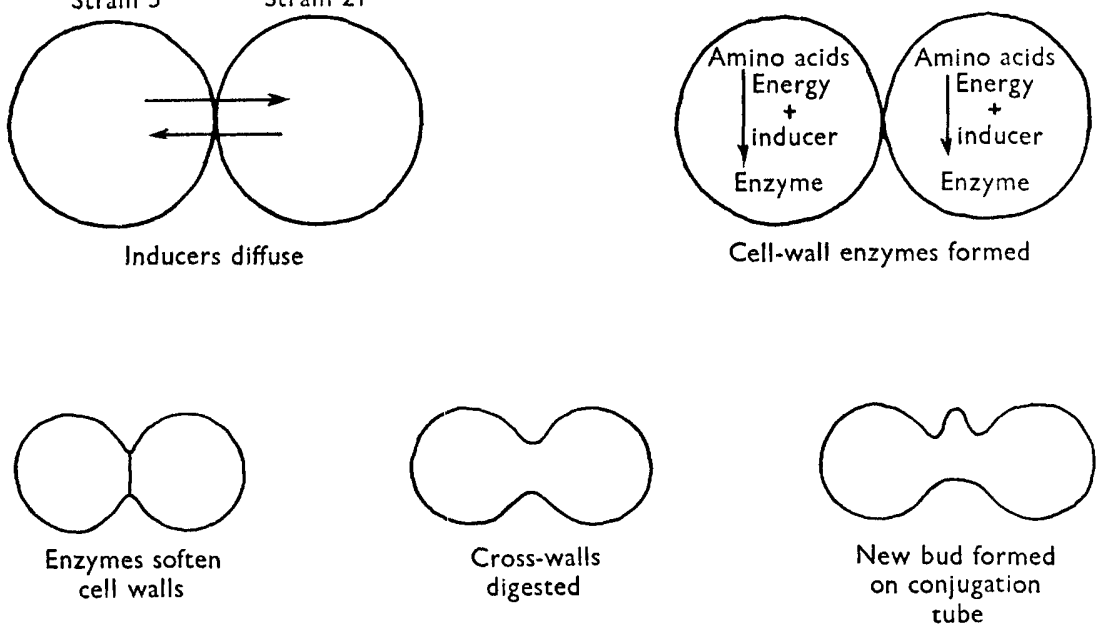

Fig. 2. Hypothetical explanation of physiological processes involved in cell fusion.

Hansenula wingei is an ideal organism for studying the physiology of conjugation, since the strong attraction between cells of opposite mating types makes it possible to aerate agglutinated cells extensively and to handle them easily in physiological experiments.

This research was supported in part by the U.S. National Science Foundation.

\section{REFERENCES}

Brock, T. D. $(1959 a)$. Biochemical basis of mating in yeast. Science, 129, 960.

Ввоск, T. D. $(1959)$ ). Mating reaction in Hansenula reingei. Relation of cell surface properties to agglutination. J. Bact. 78, 59.

Brock, T. D. $(1959 \mathrm{c})$. Is conjugation in yeast a result of induced enzyme synthesis? Bact. Proc. 1959, p. 134.

Brock, T. D. (1959d). Physiological processes in the conjugation of mating types in the yeast Hansenula roingei Wickerham. Proc. 9th int. Bot. Congr. 2, 47. 
Campbell, A. (1957). Division synchronization in a respiratory deficient yeast. J. Bact. 74, 559 .

Hawker, L. E. (1957). The Physiology of Reproduction in Fungi. Cambridge University Press.

Herman, A. (1959). Some aspects of the genetics of actidione resistance by the yeast Hansenula wingei. M.Sc. Thesis, Western Reserve University, Cleveland, U.S.A.

LEVI, J. D. (1956). Mating reactions in yeast. Nature, Lond. 177, 753.

Nickerson, W. J. \& Falcone, G. (1956). Indentification of protein disulfide reductase as a cellular division enzyme in yeasts. Science, 124, 722.

Nickerson, W. J. \& Thimann, K. V. (1941). The chemical control of conjugation of Zygosaccharomyces. Amer. J. Bot. 28, 617.

Nickerson, W. J. \& Thimann, K. V. (1943). The chemical control of conjugation in Zygosaccharomyces. II. Amer. J. Bot. 30, 94.

Spiegelman, S. \& Halvorson, H. (1953). The nature of the precursor in induced synthesis of enzymes. In Adaptation in Microorganisms. Symp. Soc. gen. Microbiol. 3, 98.

WickerhaM, L. J. (1956). Influence of agglutination on zygote formation in Hansenula roingei, a new species of yeast. C.R. Lab. Carlsberg (Sér. physiol.), 26, 423.

Wollman, E. L., JACOB, F. \& HAYES, W. (1956). Conjugation and genetic recombination in Escherichia coli K-12. Cold Spr. Harb. Symp. quant. Biol. 21, 141. 